Reprod. Nutr. Dévelop., 1988, 28 (4 B), 1193-1205

\title{
Multimodal control of pituitary gonadotropin biosynthesis. Effects of gonadal steroids, GnRH, cyclicAMP and diacyl- glycerols
}

\author{
R. COUNIS, Anna STARZEC, Maïthé CORBANI, M. JUTISZ
}

Laboratoire des Hormones Polypeptidiques, C.N.R.S., 91198 Gif-sur-Yvette, France.

\begin{abstract}
Summary. We and others have previously shown that in the rat and the sheep gonadectomy increases the translational capacity of mRNAs encoding gonadotropin subunits $\alpha, \mathrm{LH} \beta$ and $\mathrm{FSH} \beta$. Injection of estradiol or of testosterone or dihydrotestosterone depresses the translational capacity of the mRNAs. After using estradiol to induce progesterone receptors in the pituitary of castrated animals, it was determined that progesterone does enhance the inhibitory effect of estradiol. We have also observed this inhibitory effect of gonadal steroids in vitro, suggesting that at least part of the steroid action is exerted at the pituitary level. Hybridization assay (Northern blot) using oligodeoxynucleotide probes complementary to a short portion in the cDNA strand of each subunit, showed gonadal steroids to act by decreasing the number of copies of mRNAs encoding $\mathrm{LH}$ and $\mathrm{FSH}$ subunits. Using anterior pituitary cells in culture, incubated in the presence of labeled methionine, we have confirmed our previous observation that GnRH stimulates the biosynthesis of the polypeptide chains of $\mathrm{LH}$. This effect is not secondary due to $\mathrm{LH}$ release. It is not inhibited when incubation is performed in the presence of tunicamycin, an inhibitor of glycosylation. SDS-polyacrylamide gel electrophoresis of specific immunoprecipitates of polypeptides immunologically related to $\alpha$ allowed us to identify 3 forms of $\alpha$-polypeptide differing in their apparent $M_{r}: 21 \mathrm{~K}$ (partially glycosylated), 23K (authentic) and 25K (hyperglycosylated). Besides its stimulatory effect on the release and synthesis of $\mathrm{LH}, \mathrm{GnRH}$ also stimulated the release of the $23 \mathrm{~K}$ and $25 \mathrm{~K}$ forms of $\alpha$. In the presence of tunicamycin an additional $16 \mathrm{~K}$ form of apoprotein- $\alpha$ was detected which accumulated within the cells. A cAMP analogue (8-Br-cAMP), intracellular cAMP generators (choleragen, forskolin), as well as an analogue of diacylglycerols (TPA) mimic the stimulatory action of $\mathrm{GnRH}$. However, although no evidence has been obtained at present that either cAMP or diacylglycerols mediate the $\mathrm{GnRH}$ effect on the biosynthesis of the polypeptide chains of $\mathrm{LH}$, our data suggest that phosphorylation of intracellular phosphoproteins plays a major role in this process.
\end{abstract}

\section{Introduction.}

The pituitary hormones lutropin ( $\mathrm{LH}$ ) and follitropin (FSH) are members of a glycoprotein hormone family that also includes thyrotropin (TSH) and placental choriogonadotropin (CG). Each of these hormones consists of two dissimilar, non-covalently linked $\alpha$ - and $\beta$-subunits, containing one or two carbohydrate units attached to asparagine residues (Pierce and Parsons, 1981). Within a 
species, the amino acid sequences of the $\alpha$-subunits are identical, whereas they differ in the $\beta$-subunits. However, substantial homology exists in the primary structures of either of the subunits, suggesting that they evolved during phylogeny from a common ancestral gene (Fontaine and Burzawa-Gérard, 1977). Thus, with regard to their chemical structure, the biosynthesis of pituitary gonadotropins implies a complex, multi-step process that is important to elucidate with a view to examine whether it is subjected to regulation or not.

By contrast with gonadotropin release and action mechanisms, little information concerning the synthesis and processing of the subunits has emerged in the past few years. The expression of pituitary messenger RNA (mRNA) in heterologous cell-free synthesizing systems provided the first evidence that either subunit $-\alpha, \mathrm{LH} \beta$ or $\mathrm{FSH} \beta$ was translated as a precursor from separate mRNAs, and that regulation occurred at the mRNA level (for review, see Counis et al., 1982a). Recent molecular biology techniques, demonstrating that each of the LH subunit precursors is encoded by a single gene (Boothby et al., 1981; Fiddes and Goodman, 1981 ; Talmadge et al., 1983 ; Jameson et al., 1984; Tepper and Roberts, 1984), have provided tools to directly quantify their respective mRNAs. Complementary to investigation at the gene level, the synthesis and processing of LH subunits was also studied in situ using pituitary glands (Hoshina and Boime, 1982) and dispersed cells incubated in the presence of ${ }^{35} \mathrm{~S}$-methionine (Counis et al., 1987a). Combined with electrophoretic analysis, this methodology gave high resolution of the radioactive products related to $\mathrm{LH}$ processing. The role of gonadal steroids, $\mathrm{GnRH}$ and the putative intracellular mediators, cyclic AMP and diacylglycerols, was thus evaluated in the gonadotropin biosynthesis pathway.

\section{Negative control by gonadal steroids of gonadotropin gene expression.}

Using translation of rat anterior pituitary poly $\left(\mathrm{A}^{+}\right) \mathrm{mRNA}$ in an heterologous cell-free wheat germ system, we have previously shown in rats that gonadectomy increases and that injection of gonadal steroids (estradiol in females, testosterone in males) depresses the translational capacity of mRNAs encoding gonadotropin subunits $\alpha, \mathrm{LH} \beta$ and FSH $\beta$ (Counis et al., 1982b, 1983). We also observed this inhibitory effect of gonadal steroids by in vitro treatment using pituitary cells from castrated rats in primary cultures (Mogenet-Corbani, 1986). The latter results demonstrate that the inhibitory effect of steroids on the biosynthesis of gonadotropins proceeds through a direct action on the gonadotropic cell.

To investigate the mechanisms by which gonadal steroids control the synthesis of gonadotropin subunits, we used hybridization techniques to determine the content of specific mRNAs in mRNA preparations from the pituitaries of normal and ovariectomized rats and the pituitaries of ovariectomized rats treated with estradiol benzoate. Oligodeoxynucleotides (ODNs) 15 to 29 bases long, complementary to a short portion in the cDNA strand of each subunit, were chemically synthesized. The nucleotide sequence of ODNs to be synthesized was deduced from cDNA sequences either published by Godine et al. (1982) and Chin et al. (1983) and confirmed in our laboratory (as for rat $-\alpha$ and $\mathrm{LH} \beta$ ), or from 
cDNA sequences in our laboratory (as for rat FSH $\beta$ ) (unpublished data). The synthesized ODNs corresponded to the following amino acid residues of the polypeptide chains of rat gonadotropin subunits : $\alpha, 33-37$; $\mathrm{LH} \beta, 1-7$; FSH $\beta$, 23-32. Table 1 shows the sequences of the synthesized ODNs.

\section{TABLE 1}

Nucleotide sequence of the synthetic oligonucleotides used as probes to hybridize gonadotropin subunit mRNAs*.

$\alpha$ :

LH $\beta$ :

$\mathrm{FSH} \beta$ :
3'dTACCCGACAACGAAG

3'dTCCCCGGGGGAAGCCGGTGAC

3'dAGTTGTGGTGCACCACACGTCCGATGACG 5 .

* Each oligonucleotide (ODN) probe consists of a unique sequence deduced from and complementary to an internal region in the cDNA strand coding for the corresponding precursor subunit. The 15-mer $\alpha$-ODN, the 21 -mer LH $\beta$-ODN and the 29-mer FSH $\beta$-ODN thus are complementary to mRNA regions coding for amino acid residues $\mathrm{Met}^{33}-\mathrm{Phe}^{37}, \mathrm{Arg}^{1}-\mathrm{Leu}^{7}, \mathrm{Ile}^{23}-\mathrm{Cys}^{32}$ in rat $\alpha$, rat $\mathrm{LH} \beta$ and ovine $\mathrm{FSH} \beta$ subunits, respectively.

The 3 synthetic ODNs were $5^{\prime}$-end labeled and used as probes in Northern blots (Thomas, 1980) to hybridize pituitary RNAs from normal, ovariectomized and ovariectomized-estradiol benzoate-treated rats. Table 2 shows a quantitative evaluation of specific mRNAs using densitometric analysis of the films resulting from autoradiography.

It is evident from table 2 that ovariectomy resulted in a dramatic increase in the content of each of the 3 specific mRNAs encoding the precursors to $\alpha, \operatorname{LH} \beta$ and $\mathrm{FSH} \beta$. Four weeks after rats were ovariectomized, further supplementation with a single injection (s.c.) of $25 \mu \mathrm{g}$ of estradiol benzoate resulted in a decrease of all three mRNA values near to those observed in normal rats.

Similar results on the inhibition of FSH $\beta$ (Alexander and Miller, 1982) and $\alpha$-subunit synthesis (Landefeld et al., 1983 ; Landefeld and Kepa, 1984) have been reported with estradiol injected into ovariectomized ewes. Using cloned cDNA, comparable results were obtained for $\alpha$ and LH $\beta$ mRNA in sheep (Nilson et al., 1983; Papavasiliou et al., 1986) and in rats (Abbot et al., 1985; Gharib et al., 1986).

Recent data from our laboratory indicate that testosterone and dihydrotestosterone also participate in gonadotropin-mRNA regulation in male rats (MogenetCorbani, 1986). In the conditions tested, progesterone alone, or in combination with estradiol, appeared to have no effect, as seen by the very low content of progesterone receptors in the pituitaries of rats 3 weeks after ovariectomy. However, progesterone receptors are estradiol-inducible, and we have shown that when ovariectomized rats were pretreated with estradiol, progesterone enhanced the inhibitory effect of estradiol on mRNA encoding the $\alpha$ - and $\beta$-subunits of LH and FSH (Corbani et al., 1987).

Gonadal steroids negatively regulate the biosynthesis pathway of gonadotropin subunits. Because they proceed by lowering the number of copies of mRNAs encoding gonadotropin subunits, it is most likely that gonadal steroids 
Changes in pituitary content of $\alpha-, L H \beta$ - and FSH $\beta$-mRNAs after ovariectomy and after estradiol-supplementation of ovariectomized female rats*.

\begin{tabular}{lccc}
\hline & $\begin{array}{c}\text { Intact } \\
\text { rat }\end{array}$ & OVX rat & $\begin{array}{c}\text { OVX rat } \\
+ \\
\text { estradiol }\end{array}$ \\
\hline$\alpha$-mRNA & $0.375 \pm 0.018$ & $3.385 \pm 0.085$ & $0.521 \pm 0.025$ \\
LH $\beta$-mRNA & $100 \%$ & $903 \%$ & $139 \%$ \\
FSH $\beta$-mRNA & $0.075 \pm 0.008$ & $0.892 \pm 0.026$ & $0.123 \pm 0.012$ \\
& $100 \%$ & $1189 \%$ & $164 \%$ \\
& $0.012 \pm 0.004$ & $0.056 \pm 0.006$ & $0.022 \pm 0.003$ \\
& $100 \%$ & $467 \%$ & $183 \%$ \\
\hline
\end{tabular}

* RNA was isolated from pituitaries of 3 month-old female rats, either intact or 3 weeks after ovariectomy. Half of the ovariectomized rats received 48 hours before sacrifice a single injection of $25 \mu \mathrm{g}$ estradiol and the other half was sham-injected. Glyoxal-denatured RNA was electrophoresed on $1.7 \%$ agarose gel and transferred onto nylon filter. Oligoprobes were ${ }^{32} \mathrm{P}$-labeled at the $5^{\prime}$-terminus and hybridizations were performed for $48-72 \mathrm{~h}$ at $35^{\circ} \mathrm{C}\left(\alpha\right.$-ODN, FSH $\beta$-ODN) or $45^{\circ} \mathrm{C}(\mathrm{LH} \beta$-ODN) in $4 \times$ SSC, $10 \mathrm{mM}$ EDTA, $2 \mathrm{mM}$ Na-pyrophosphate, $200 \mu \mathrm{g} / \mathrm{ml}$ Ficoll $-400,200 \mu \mathrm{g} / \mathrm{ml}$ bovine serum albumine, $200 \mu \mathrm{g} / \mathrm{ml}$ polyvinyl pyrrolidone, $0.5 \%$ sarkosyl and $250 \mu \mathrm{g} / \mathrm{ml}$ denatured salmon sperm DNA; After autoradiography of the filters, the amount of the radioactivity hybridized to specific mRNA species was quantified by scanning densitometry and results were expressed as arbitrary units of area \pm SEM (3 determinations).

act on the expression of specific genes. Interestingly, gonadal steroids were recently observed to have strong stimulatory action on both $\alpha$ (Counis et al., $1987 \mathrm{~b}$ ) and $\beta$ (Trinh et al., 1986) subunits of the single gonadotropin (GTH) in juvenile teleosts. The opposite effects of these steroids in mammals and in juvenile teleosts may result from phylogenetic differences in the structure of regulatory sequences in the genes or from changes in their molecular environment in the cell, suggesting a possible complex regulatory process which requires further investigation.

\section{$\mathrm{GnRH}$-induced regulation of the synthesis of $\mathrm{LH}$ subunits.}

GnRH stimulates the synthesis of the polypeptide moiety of LH subunits. In 1978 our laboratory reported that $\mathrm{GnRH}$ stimulates the synthesis of the polypeptide chains of pituitary gonadotropins as well as their release (Khar et al., 1978). In this early research, we used cultures of pituitary cells incubated in the presence of labeled amino acids. Neosynthesized gonadotropins were isolated from cultured cells and media using immunoprecipitation with specific antisera.

Because a controversy developed as to the mechanisms involved in $\mathrm{GnRH}$ action on gonadotropin synthesis and/or processing, we have recently reevaluated the effect of $\mathrm{GnRH}$ using a more reliable and precise methodology (Starzec et al., 1986). Cultures of dispersed anterior pituitary cells from normal or castrated adult male rats were incubated in the presence of ${ }^{35} \mathrm{~S}$-methionine and in the presence or absence of $\mathrm{GnRH}$. Using specific antisera, labeled polypeptides 
were isolated separately from the media and the cells and were characterized by SDS-polyacrylamide slab gel electrophoresis (SDS-PAGE). The bands, revealed by fluorography and corresponding to polypeptides immunologically related to the $\alpha$ and $\beta$-subunits, were excised and counted for their radioactivity. Only the dissociated forms of $\mathrm{LH}$ subunits were detected after SDS-PAGE.

Table 3 shows the effect of $40 \mathrm{nM} \mathrm{GnRH}$ on the incorporation of ${ }^{35} \mathrm{~S}$ methionine into total proteins and into polypeptides immunologically related to the $\alpha$ and $\mathrm{LH} \beta$-subunits. In parallel, the effect of $\mathrm{GnRH}$ on the release of $\mathrm{LH}$ from the pituitary cells into the medium was also recorded.

TABLE 3

Effect of $\mathrm{GnRH}$ on the incorporation of ${ }^{35} \mathrm{~S}$-methionine into total protein and into polypeptides immunologically related to $L H$ subunits*.

\begin{tabular}{|c|c|c|c|c|c|}
\hline \multirow{3}{*}{ Group } & \multirow{3}{*}{$\begin{array}{c}\text { Total } \\
\text { protein }^{b}\end{array}$} & \multicolumn{4}{|c|}{ Radioactivity $\left(\mathrm{cpm} \times 10^{3}\right)$ incorporated into ${ }^{a}$} \\
\hline & & \multicolumn{2}{|c|}{$\alpha$} & \multicolumn{2}{|c|}{$\mathrm{LH} \beta$} \\
\hline & & $i p^{c}$ & PAGE $^{d}$ & $i p^{c}$ & PAGE $^{d}$ \\
\hline Control & $\begin{array}{c}38420 \pm 2830 \\
(100 \%)^{\mathrm{e}}\end{array}$ & $\begin{array}{c}211.31 \pm 4.43 \\
(0.55 \%)\end{array}$ & $\begin{array}{c}19.70 \pm 0.45 \\
(0.05 \%)\end{array}$ & $\begin{array}{c}146.32 \pm 3.93 \\
(0.38 \%)\end{array}$ & $\begin{array}{c}2.25 \pm 0.35 \\
(0.006 \%)\end{array}$ \\
\hline $\begin{array}{l}\text { GnRH } \\
(40 \mathrm{nM})\end{array}$ & $\begin{array}{c}37260 \pm 1740 \\
(100 \%)^{\mathrm{e}} \\
\mathrm{ns}^{\mathrm{f}}\end{array}$ & $\begin{array}{c}241.87 \pm 5.31 \\
(0.65 \%) \\
n s\end{array}$ & $\begin{array}{c}63.90 \pm 0.55 \\
(0.17 \%) \\
P \leqslant 0.01\end{array}$ & $\begin{array}{c}153.68 \pm 5.03 \\
(0.41 \%) \\
\mathrm{ns}\end{array}$ & $\begin{array}{c}5.65 \pm 0.38 \\
(0.015 \%) \\
P \leqslant 0.01\end{array}$ \\
\hline
\end{tabular}

* Cultured anterior pituitary cells were incubated for $5 \mathrm{~h}$ in the presence of ${ }^{35} \mathrm{~S}$-methionine and in the absence (control) or in the presence of $40 \mathrm{nM} \mathrm{GnRH}$. Polypeptides in cells and in the media were subjected to immunoprecipitation using specific antisera to $\alpha$ and $\mathrm{LH} \beta$ subunits. Radioactive material in the immunoprecipitates was either counted or used for analysis by SDS-PAGE. Labeled polypeptides, related to $\alpha$ and $\mathrm{LH} \beta$, were then excised from the gel, solubilized and counted.

a Values (cells + medium) were expressed as counts per $\min / 3 \times 10^{6}$ cells. b TCA (10\%) precipitate. "Radioactivity contained in the crude immunoprecipitate. ${ }^{d}$ Bands excised from the gel after SDS-PAGE. ${ }^{e}$ Percent of radioactivity $v s$ radioactivity in total proteins $\left({ }^{\mathrm{b}}\right)$. ${ }^{\mathrm{f}}$ Significance $v s$ control values $(\mathrm{ns}=$ non significant).

It is evident from table 3 that, in the presence of $\mathrm{GnRH}$, the incorporation of label into total protein does not differ significantly from that in the control experiment. In contrast, incorporation into LH subunits isolated by SDS-PAGE was very significantly increased by $\mathrm{GnRH}$. When radioactivity was measured in the immunoprecipitates, at a step before the SDS-PAGE analysis, no significant effect of $\mathrm{GnRH}$ was detectable compared to the control. This was due to the presence in the immunoprecipitates of radioactive contaminants which were removed in the course of SDS-PAGE.

Dose response and time-course experiments have shown that the effect of $\mathrm{GnRH}$ is dose $(0.1 \mathrm{nM}-10 \mathrm{nM})$ and time-dependent and that it is detectable only after a time-lag of $90 \mathrm{~min}$ (Starzec, 1987). Finally, we checked that an increase 
in medium concentrations of potassium ion to $59 \mathrm{mM}$ (known to induce aspecific release of pituitary hormones) was unable to mimic the action of GnRH on ${ }^{35} \mathrm{~S}$-methionine incorporation.

Tunicamycin does not prevent the stimulatory effect of $G n R H$ on the synthesis of $L H$ polypeptide chains. - As some investigators (Liu and Jackson, 1978,1985 ; Azhar et al., 1978 ; Vogel et al., 1986) supported the idea that $\mathrm{GnRH}$ stimulates the glycosylation of gonadotropin subunits rather than the synthesis of their polypeptide chains, we decided to determine whether or not GnRH would stimulate the incorporation of ${ }^{35} \mathrm{~S}$-methionine into the polypeptide chains of $\mathrm{LH}$ when the glycosylation process was blocked. To do this, cells were incubated in the presence of tunicamycin (TK), a glucosamine-containing antibiotic (Takatsuki et al., 1971) known to interfere directly with the glycosylation reactions leading to the formation of mannose- and $\mathrm{N}$-acetylglucosamine-containing glycoproteins (Tkacz and Lampen, 1975).

In a first series of experiments, we determined the conditions in which TK extensively inhibited the incorporation of carbohydrates into polypeptide chains of LH without inhibiting their biosynthesis. As before, we used a culture of dispersed pituitary cells from castrated male rats. We observed that when the cells were first preincubated for $1 \mathrm{~h}$ in the presence of $1 \mu \mathrm{g} / \mathrm{ml}$ of TK, prior to incubation for $5 \mathrm{~h}$ in the presence of ${ }^{35} \mathrm{~S}$-methioinine, no effect or only a weak inhibitory one $(<10 \%)$ of TK was obtained in the amount of radioactivity incorporated into the total proteins. Although the blockade of glycosylation was not complete, these conditions seemed satisfactory because longer pretreatments or higher doses of TK resulted in a decrease of $\alpha$ and LH $\beta$ syntheses (Starzec, 1987).

In the conditions used for SDS-PAGE, $x$-subunit can usually be detected in 3 molecular forms differing in their apparent $\mathrm{M}_{\mathrm{r}}(21 \mathrm{~K}, 23 \mathrm{~K}$ and $25 \mathrm{~K})$ (Counis et al., 1987a). Pulse-chase experiments showed that the $21 \mathrm{~K}$ peptide, which represents partially glycosylated $\alpha$, was successively converted into $23 \mathrm{~K}$ (authentic $\alpha$ ) and $25 \mathrm{~K}$, a « hyperglycosylated » form of $\alpha$, with the spontaneous release of the two larger forms into the medium. With regard to $\mathrm{LH} \beta$, a single polypeptide of $M_{r} 19 \mathrm{~K}$ was resolved by electrophoresis from immunoprecipitated material primarily present in cells ; this polypeptide only occurred in trace amounts in the medium.

As shown in figure 1, when cells were incubated in the presence of tunicamycin, a $16 \mathrm{~K}$ form was observed in the cells (in addition to the 3 forms of $\alpha$ mentioned above) which corresponded to apoprotein $\alpha$; this form was not found in the medium. This $16 \mathrm{~K}$ protein $\alpha$ was characterized using, as a control, the precursor of apoprotein $\alpha$ obtained by translation of rat pituitary mRNA in a heterologous cell-free system. As this precursor contained a signal peptide, in addition to the apoprotein, its $M_{r}$ was close to $17 \mathrm{~K}$ (fig. 1 ). The fact that in the conditions used, the glycosylation of $\alpha$ was not completely inhibited is demonstrated by the presence of radioactive forms $23 \mathrm{~K}$ and $25 \mathrm{~K}$. Because the levels of neosynthesized $\mathrm{LH} \beta$ in the anterior pituitary cells was more than 10 times lower than that of $\alpha$, its detection was rather difficult and a very large number of cells was needed. For this reason, we restricted our demonstration to the $\alpha$-subunit. 


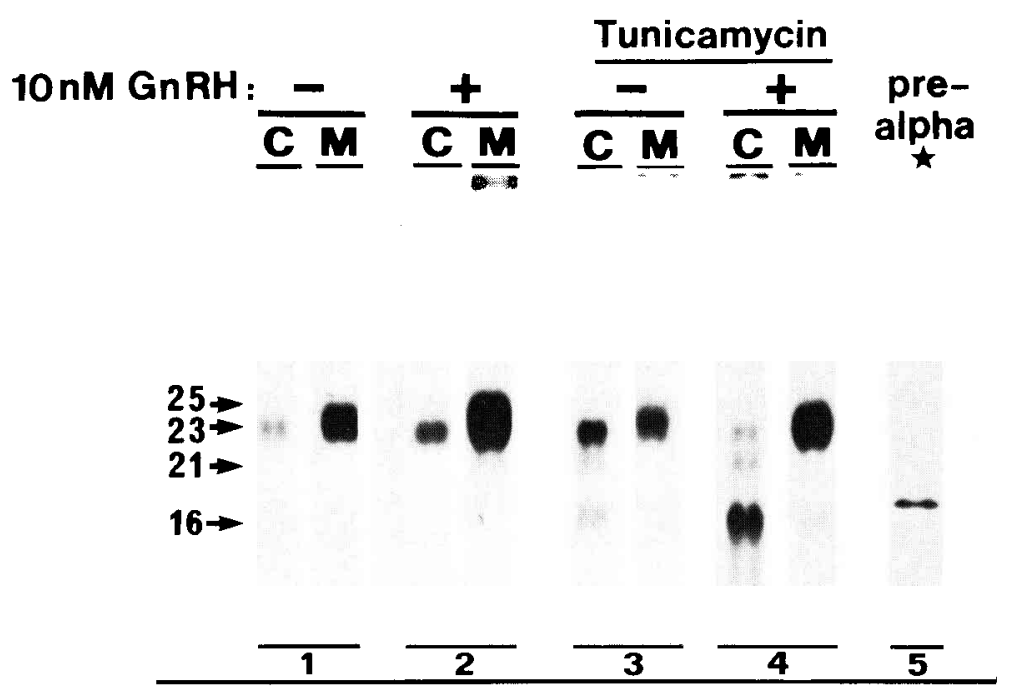

FIG. 1. - Effect of $G n R H$ and tunicamycin on the biosynthesis of the $\alpha$-subunit of glycoprotein hormones. Polypeptides immunologically-related to $\alpha$-subunit were isolated from cells (C) and from media $(M)$ after incubation of cultured anterior pituitary cells for $5 \mathrm{~h}$ in the presence of $\left[{ }^{35} \mathrm{~S}\right] \mathrm{Met}$, and analysed by $17 \%$ SDS-polyacrylamide gel electrophoresis. Gels were processed for fluorography and exposed to Kodak X-AR films. 1: Basal synthesis; 2 : incubation in the presence of $10 \mathrm{nM} \mathrm{GnRH} \mathrm{;} \mathrm{3-4} \mathrm{:} \mathrm{as} \mathrm{in} \mathrm{1-2} \mathrm{except} \mathrm{that} \mathrm{cells} \mathrm{were} \mathrm{treated} \mathrm{with} 1 \mu \mathrm{g} / \mathrm{ml}$ tunicamycin $1 \mathrm{~h}$ prior addition of $\left.{ }^{35} \mathrm{~S}\right] \mathrm{Met}$ in the absence (3) and in the presence (4) of $10 \mathrm{nM} \mathrm{GnRH} ; 5$ : co-electrophoresis of $\left[{ }^{35} \mathrm{~S}\right]$ Met-labeled $\alpha$-precursor isolated from translation media which synthesis was directed by rat anterior pituitary mRNA in the presence of wheat-germ embryo extract.

In the presence of $\mathrm{GnRH}(10 \mathrm{nM})$, the synthesis rate of the polypeptide chain of $\alpha$ significantly increased, whether glycosylation was blocked or not, suggesting that $\mathrm{GnRH}$ was directly involved in the stimulation of the incorporation of amino acids into the subunit. GnRH also readily induced the release of the newly synthesized $\alpha$-subunit. This stimulatory effect of $\mathrm{GnRH}$ was more pronounced for 
the highly glycosylated forms of $\alpha(23 \mathrm{~K}$ and $25 \mathrm{~K})$ compared to the $16 \mathrm{~K}$ form which remained primarily intracellular. This also suggests that carbohydrates play a role in the secretory process of glycoproteins.

Thus, our data indicate that $\mathrm{GnRH}$ specifically stimulated the synthesis of $\mathrm{LH}$ polypeptide chains. A series of 9 similar, totally independent experiments have shown that $\mathrm{GnRH}$ has a highly significant stimulatory effect on the incorporation of labeled methionine by the $\alpha$-subunit $(3.4 \pm 1.5 ; \mathrm{P} \leqslant 0.05)$ and by the L.H $\beta$-subunit $(2.4 \pm 0.5 ; \mathrm{P} \leqslant 0.05)$, whatever the dispersion of counts per min values. This effect is not secondary due to the release of $\mathrm{LH}$, as shown by experiments performed in high-potassium media. It is not dependent on glycosylation as the stimulatory action of $\mathrm{GnRH}$ on the incorporation of labeled methionine persists when glycosylation is inhibited by tunicamycin. These results suggest that the effect of $\mathrm{GnRH}$ on the increased glycosylation may be secondary due to the primary effect of $\mathrm{GnRH}$ on the synthesis rate of the apoprotein moieties of $\mathrm{LH}$. Finally, besides its well known stimulatory effect on $\mathrm{LH}$ release, $\mathrm{GnRH}$ also stimulates the release of the native form of $\alpha$-subunit as well as its " hyperglycosylated " derivative. The "hyperglycosylated " form of $\alpha$ was first identified in bovine pituitary (Parsons and Pierce, 1984); however its physiological role, if any, is not yet known.

\section{Intracellular mediators mimic GnRH action on the synthesis of LH subunits.}

To investigate the mechanism (s) by which $\mathrm{GnRH}$ acts on the synthesis of $\mathrm{LH}$ subunits, we checked the effect of well-known intracellular mediators of hormone action such as CAMP and diacylglycerols (DAG).

As far as CAMP is concerned, many results obtained in vitro and in vivo in our laboratory and in other laboratories (for review, see Bérault et al., 1980) show that there is no correlation between $\mathrm{LH}$ release and cAMP increase in anterior pituitary cells or tissue. Compared to those necessary for $\mathrm{GnRH}$ induction of $\mathrm{LH}$ release, longer incubation times and higher doses of $\mathrm{GnRH}$ are generally required to enhance CAMP accumulation in anterior pituitary. In most of the tissues in which CAMP mediates a hormone action, the level of the nucleotide increases a few minutes after the beginning of hormonal stimulation, but this was not the case with $\mathrm{GnRH}$, which induced significant cAMP accumulation in vitro only after the pituitary cells and tissue had been incubated for more than $1 \mathrm{~h}$.

More recently, a complex hormone-dependent phospholipid degradation system has been shown to participate in the acute $\mathrm{GnRH}$-induced release of pituitary gonadotropins (for review, see Naor et al., 1986). This mechanism implicates the activation of protein kinase $C$ by DAG resulting from the hydrolysis of membrane phosphatidyl inositol.

To study the possible involvement of cAMP in the synthesis of LH subunits, we examined the effect on pituitary cells in culture of 8-Br-cAMP, an analogue of cAMP known for its ability to enter the cell, as well as the effect of the intracellular cAMP generators, choleragen and forskolin. To investigate DAG action, we used a potent analogue, tetradecanoylphorbol acetate (TPA). 
Table 4 shows the effects of $\mathrm{GnRH}$ and the intracellular mediators on the incorporation of labeled methionine into total protein and into subunits $\alpha$ and $\mathrm{LH} \beta$. Our results demonstrated that exogenous and intracellular CAMP, as well as the analogue of diacylglycerols, were able to induce a large increase in the synthesis of LH subunits, as GnRH does.

\section{TABLE 4}

Effect of Br-cAMP, cholera toxine and TPA on the incorporation of ${ }^{35} S$-methionine into total proteins and polypeptides immunologically-related to $\alpha$ and LH polypeptide chains*.

Radioactivity $\left(\mathrm{cpm} \times 10^{3}\right)$ incorporated into ${ }^{a}$

\begin{tabular}{lccc} 
& \multicolumn{2}{c}{ Radioactivity } & $\left(\mathrm{cpm} \times 10^{3}\right)$ incorporated into $^{\mathrm{a}}$ \\
\cline { 2 - 4 } & $\begin{array}{c}\text { Total } \\
\text { protein }^{\mathrm{b}}\end{array}$ & $\alpha$-subunit $^{\mathrm{c}}$ & LH $\beta^{\mathrm{c}}$ \\
\cline { 2 - 4 } Control & $20990 \pm 1550$ & $16.1 \pm 0.8$ & $2.1 \pm 0.3$ \\
& $(100 \%)^{\mathrm{d}}$ & $(100 \%)$ & $(100 \%)$ \\
$10 \mathrm{nM}$ GnRH & $19670 \pm 2060$ & $38.3 \pm 1.0$ & $4.0 \pm 0.5$ \\
$1 \mathrm{mM}$ 8-Br-cAMP & $(94 \%)^{\mathrm{d}}$ & $(238 \%)$ & $(190 \%)$ \\
& $24770 \pm 1020$ & $44.3 \pm 0.7$ & $3.9 \pm 0.4$ \\
$6 \mathrm{nM}$ cholera toxin & $(118 \%)^{\mathrm{d}}$ & $(275 \%)$ & $(186 \%)$ \\
& $22240 \pm 1150$ & $46.8 \pm 1.0$ & $5.0 \pm 0.3$ \\
$50 \mathrm{nM}$ TPA & $(106 \%)^{\mathrm{d}}$ & $(291 \%)$ & $(238 \%)$ \\
& $26120 \pm 1310$ & $68.3 \pm 0.9$ & $6.3 \pm 0.5$ \\
& $(125 \%)^{\mathrm{d}}$ & $(424 \%)$ & $(300 \%)$ \\
& & &
\end{tabular}

* Cultured anterior pituitary cells were incubated for $5 \mathrm{~h}$ in the presence of ${ }^{35} \mathrm{~S}$-methionine and in the absence (control) or in the presence of $\mathrm{GnRH}$ or another tested product. Polypeptides in cells + media were subjected to immunoprecipitation using specific antisera to $\alpha$ and LH $\beta$ subunits, then submitted to SDS-PAGE analysis. Labeled polypeptides, related to $\alpha$ and $\mathrm{LH} \beta$ were then excised from the gel, solubilized and counted.

a Values (cells + medium) were expressed as counts per $\mathrm{min} / 3 \times 10^{6}$ cells. ${ }^{\mathrm{b}} \mathrm{TCA}(10 \%)$ precipitate. "Radioactivity in bands excised from SDS-polyacrylamide gels after fluorography. d Percent of radioactivity $v s$ radioactivity in control cells.

At this stage of our experiments, it appeared interesting to examine whether the effects of $\mathrm{GnRH}$ and of intracellular mediators, as well as the effects of 8-Br-cAMP and TPA, proceeded via different intracellular routes. With this objective, the incorporation of labeled methionine into subunits $\alpha$ and LH $\beta$ was measured in conditions where each of the compounds tested was added alone, or in combination, into the incubation medium. In all cases, TPA appeared to induce the highest incorporation rate of all. However, the combination of TPA, $\mathrm{GnRH}$ and 8-Br-cAMP did not show increased incorporation of the label compared to TPA alone, and no cumulative effect was observed in any of the different possible combinations tested.

These later data strongly suggest the possibility that $\mathrm{GnRH}$ participates with CAMP and diacylglycerols, or via these latter compounds, in the processes leading to the stimulation of the synthesis of the polypeptide chains of LH subunits. However, the exact intracellular mechanisms by which $\mathrm{GnRH}$ operates on this 
synthesis, and how cAMP and DAG are involved, remain to be elucidated. Indeed, further investigation is necessary to determine whether cAMP and DAG could be considered as intracellular mediators in these mechanisms.

\section{Conclusions.}

Data from our laboratory and those reported by others demonstrate that the synthesis of pituitary gonadotropins is under dual hormonal control, i.e. both gonadal steroids and $\mathrm{GnRH}$ are involved. The data suggest that negative control by steroids occurs at the transcriptional level of the specific genes coding for gonadotropin subunits. The stimulatory effect of $\mathrm{GnRH}$ probably proceeds via different mechanisms which remain to be elucidated. 8-Br-cAMP, choleratoxin, forskolin and TPA mimic this effect of GnRH. Furthermore, the effects of $\mathrm{GnRH}$, 8-Br-cAMP and TPA do not appear to be additive. However, at present we have no evidence that either CAMP or DAG mediates the effect of $\mathrm{GnRH}$ on the synthesis of LH subunits. At the very most, our data strongly suggest that protein phosphorylation plays an important role in this mechanism.

Reçu en octobre 1987. Accepté en avril 1988.

Acknowledgements. - We are indebted to Dr J. G. Pierce for his generous gifts of antisera to denatured bovine LH subunits and NIDDK, the National Hormone and Pituitary Program, University of Maryland, School of Medicine, Baltimore, MD, USA, for rat LH and FSH RIA kits. We also wish to thank Mr. M. Poissonnier (this laboratory) for providing us with highly purified ovine LH subunits, Dr. D. McDougal (The Cruachan Chemicals Inc., Livingstone (Scotland), Dr. C. Jacq (Centre de Génétique Moléculaire, C.N.R.S., Gif-surYvette) and Dr. G. Fayat (Laboratoire de Biochimie, Ecole Polytechnique, Palaiseau) for the synthesis of oligodeoxynucleotides corresponding to a part of the sequence of $\alpha, \mathrm{LH} \beta$ and $\mathrm{FSH} \beta$. The valuable technical assistance of Mme G. Ribot is acknowledged. A.S. was a recipient of the "Fondation pour la recherche Médicale » fellowship. This work was supported by I.N.R.A. (A.I.P. " Hormones hypophysaires et fonction de reproduction chez les Vertébrés » no 4534), and by a grand from «Fondation de Recherche en Hormonologie $)$.

Résumé. Contrôle multimodal de la biogenèse des hormones gonadotropes hypophysaires. Effet des stéroïdes gonadiques, du GnRH, de l'AMP cyclique et des diacylglycérols.

En utilisant la traduction de mRNA dans un système acellulaire hétérologue, neutre (extrait de germes de blé), on peut montrer que la gonadectomie augmente, - et à l'inverse, l'injection d'œstradiol, de testostérone ou de dihydrotestostérone diminue l'expression des mRNAs des sous-unités $\alpha$ et $\beta$ des gonadotropines hypophysaires. Récemment, nous avons montré que la progestérone aussi peut avoir un effet inhibiteur qui amplifie l'action de l'œstradiol requise pour induire au préalable chez la ratte ovariectomisée les récepteurs de la progestérone. Ces mêmes effets des stéroïdes gonadiques ont été retrouvés in vitro en traitant des cellules antéhypophysaires en culture primaire, preuve que cette action s'effectue au moins en partie directement au niveau hypophysaire. L'hybridation directe ( northern » blot) à l'aide d'oligosondes radioactives, spécifiques des mRNAs de $\alpha, \mathrm{LH} \beta$ et $\mathrm{FSH} \beta$ permet d'établir que les fluctuations de leur expression, précédemment observées, sont causées par les variations correspondantes de leur contenu 
hypophysaire en terme de nombre de copies. Nous avons également étudié la biosynthèse des sous-unités $\alpha$ et LH $\beta$ in situ dans des cellules antéhypophysaires en culture. Après marquage par la ${ }^{35} \mathrm{~S}$-méthionine, nous avons associé l'immunoextraction et l'analyse électrophorétique pour caractériser les différentes formes de $\alpha$ et $\mathrm{LH} \beta$ immunoréactives. Après $5 \mathrm{~h}$ d'incubation, la sous-unité $\alpha$ se trouve sous 3 formes de $M_{r} 21 \mathrm{~K}$ (partiellement glycosylée), 23K (authentique) et 25K (« super-glycosylée »), la sous-unité LH $\beta$ sous une seule forme seulement de $M_{r} 19 \mathrm{~K}$. En utilisant ce modèle très résolutif, nous avons établi l'action stimulante du GnRH sur la synthèse des sous-unités de LH, confirmant des résultats plus anciens du laboratoire. En suivant le matériel immunoréactif dans les cellules et dans le milieu de culture, nous avons observé que le $\mathrm{GnRH}$, non seulement stimule la synthèse et la libération de $L H$, mais aussi stimule la libération dans le milieu des sous-unités $\alpha 23$ et $25 \mathrm{~K}$ néosynthétisées. En outre, si l'on bloque par la tunicamycine les processus de glycosylation, les effets du $\mathrm{GnRH}$ persistent: ils se manifestent par une production accrue d'une forme de $\alpha$ de $M_{r} 16 \mathrm{~K}$ (apopeptide) qui s'accumule à l'intérieur des cellules. Un analogue du CAMP, le 8-Br-cAMP mais également les substances qui induisent la production intracellulaire de cAMP endogène (toxine cholérique, forskoline), de même que l'analogue des diacylglycérols (TPA) sont capables comme le GnRH de stimuler la production des sous-unités de LH. Bien que nous n'ayons pas obtenu de preuve que ces messagers intracellulaires bien connus soient les médiateurs de l'action du $\mathrm{GnRH}$, ils apparaissent être impliqués dans les processus de régulation de la biosynthèse de $\mathrm{LH}$ bt suggèrent notamment la mise en jeu de mécanismes de phosphorylation.

\section{References}

ABBOT S. D., DOCHERTY K., ROBERTS J. L., TEPPER M. A., CHIN W. W., CLAYTON R. N., 1985. Castration increases luteinizing hormone subunit messenger RNA levels in male rat pituitaries. J. Endocrinol., 107, R1-R4.

ALEXANDER D. C., MILLER W. L., 1982. Regulation of ovine follicle-stimulating hormone $\beta$-chain mRNA by $17 \beta$-estradiol in vivo and in vitro. J. biol. Chem., 257, 2282-2286.

AZHAR S., REEL J. R., PASTUSHOK C. A., MENON K. M. J., 1978. LH biosynthesis and secretion in rat pituitary cell cultures : stimulation of $\mathrm{LH}$ glycosylation and secretion by $\mathrm{GnRH}$ and an agonistic analogue and blockade by an antagonistic analogue. Biochem. Biophys. Res. Commun., 80, 659-666.

BERAULT A., THEOLEYRE M., JUTISZ M., 1980. Binding of GnRH to the pituitary plasma membranes, cyclic AMP, and LH release. In JUTISZ M., McKERNS K. W., Synthesis and release of adenohypophyseal hormones, Plenum Press, New York and London, pp. 441 -462.

BOOTHBY M., RUDDON R. W., ANDERSON C., MCWILLIAMS D., BOIME I., 1981. A single gonadotropin $\alpha$-subunit gene in normal tissue and tumor-derived cell lines. J. biol. Chem., 256, 5121-5127

CHIN W. W., GODINE J. E., KLEIN D. R., CHANG A. S., TAN L. K., HABENER J. F., 1983. Nucleotide sequence of the cDNA encoding the precursor of the $\beta$ subunit of rat lutropin. Proc, nat. Acad. Sci. USA, 80, 4649-4653.

CORBANI M., WOLINSKA-WITORT E., COUNIS R., JUTISZ M., 1987. Progesterone together with estradiol negatively regulates in the rat the mRNA encoding the pituitary gonadotropin. Program of the 69th Annual Meeting of the Endocrine Society, Indianapolis, Abst. no 475.

COUNIS R., CORBANI M., JUTISZ M., 1982a. Studies on cell-free biosynthesis of lutropin (LH) and characterization of its subunit precursors. In MOTTA M., ZANISI M., PIVA F., Pituitary hormones and related peptides, Acad. Press, London and New York, pp. 49-61.

COUNIS R, CORBANI M., JUTISZ M., 1982b. Régulation de la biosynthèse des gonadotropines hypophysaires. In TIXIER-VIDAL A., RICHARD Ph., Régulations cellulaires multihormonales en neuroendocrinologie, Colloques de I'INSERM, Paris, 110, pp. 509-524.

COUNIS R., CORBANI M., JUTISZ M., 1983. Estradiol regulates mRNAs encoding precursors to rat lutropin (LH) and follitropin (FSH) subunits. Biochem. Biophys. Res. Commun., 114, 65-72. 
COUNIS R., STARZEC A., JUTISZ M., 1987a. Maturation des sous-unités de LH in situ dans les cellules antéhypophysaires en culture : effet du GnRH. Path. Biol. (Paris), 35, 1147-1151.

COUNIS R., DUFOUR S., RIBOT G., QUERAT B., FONTAINE Y.-A., JUTISZ M., 1987b. Estradiol has inverse effects on pituitary glycoprotein hormone $\alpha$-subunit messenger ribonucleic acid in the immature European eel and the gonadectomized rat. Endocrinology, 121, 1178-1184.

FIDDES J. C., GOODMAN H. M., 1981. The gene encoding the common alpha subunit of the four human glycoprotein hormones. J. mol. appl. Genet, 1, 3-18.

FONTAINE Y.-A., BURZAWA-GERARD E., 1977. Esquisse de l'évolution des hormones gonadotropes et thyréotropes des vertébrés. Gen. comp. Endocr., 32, 341-347.

GHARIB S. D., BOWERS S. M., NEED L. R., CHIN W. W., 1986. Regulation of rat luteinizing hormone subunit messenger ribonucleic acids by gonadal steroid hormones. $J$. clin. Invest., 77, 582-589

GODINE J. E., CHIN W. W., HABENER J. F., 1982. $x$ subunit of rat pituitary glycoprotein hormones. Primary structure of the precursor determined from the nucleotide sequence of cloned cDNAs. J. biol. Chem., 257, 8368-8371.

HOSHINA H., BOIME I., 1982. Combination of rat lutropin subunits occurs early in the secretory pathway. Proc. nat. Acad. Sci. USA, 79, 7649-7653.

JAMESON L., CHIN W. W., HOLLENBERG A. N., CHANG A. S., HABENER J. F., 1984. The gene encoding the $\beta$-subunit of rat luteinizing hormone. Analysis of gene structure and evolution of nucleotide sequence. $J$. biol. Chem., 259, 15474-15480

KHAR A., DEBELJUK L., JUTISZ M., 1978. Biosynthesis of gonadotropins by rat pituitary ceils in culture and in pituitary homogenates : effect of gonadotropin-releasing hormone. Mol. cell. Endocr., 12, 53-65.

LANDEFELD T. D., KEPA J., 1984. Regulation of LH beta subunit mRNA in the sheep pituitary gland during different feedback states of estradiol. Biochem. Biophys. Res. Commun., 122. 1307-1313.

LANDEFELD T. D., KEPA J., KARSH F. J., 1983. Regulation of $\alpha$-subunit synthesis by gonadal steroid feedback in the sheep anterior pituitary. J. biol. Chem., 258, 2390-2393.

LIU T. C., JACKSON G. L., 1978. Modifications of luteinizing hormone biosynthesis and release by gonadotropin-releasing hormone, cycloheximide and actinomycine D. Endocrinology, 103. 1253-1263.

LIU T. C., JACKSON G. L., 1985. Synthesis and release of luteinizing hormone in vitro by rat anterior pituitary cells : effect of gallopamil hydrochloride (D 600) and pimozide. Endocrinology, 117, 1608-1614.

MOGENET-CORBANI M., 1986. Régulation par les stéroides gonadiques du taux des RNA messagers codant pour les gonadotropines hypophysaires chez le rat. Sc. D. Thesis, Univ. Paris 6.

NAOR Z., LIMOR R., HERMON J., 1986. Phospholipid turnover, $\mathrm{Ca}^{2+}$ mobilization and protein kinase $C$ activation in GnRH action on pituitary gonadotrophs. In FINK G., HARMAR A. J., McKERNS K. W., Neuroendocrine molecular biology, Plenum Press, New York and London, pp. 113-123.

NILSON J. H., NEJEDLIK M. T., VIRGIN J. B., CROWDER M. E., NETT T. M., 1983. Expression of $\alpha$-subunit and luteinizing hormone $\beta$-genes in the ovine anterior pituitary; estradiol supresses accumulation of mRNAs for both $\alpha$-subunit and luteinizing hormone- $\beta$. J. biol. Chem., 258, 12087-12090.

PAPAVASILIOU S. S., ZMEILI S., HERBON J., DUNCAN-WELDON J., MARSHALL J.C., LANDEFELD T. D., 1986. $\alpha$ and luteinizing hormone $\beta$ messenger ribonucleic acid (RNA) of male and female rats after castration: Quantitation using an optimized RNA dot blot hybridization assay. Endocrinologv, 119, 691-698.

PARSONS T. F., PIERCE J. G., 1984. Free $\alpha$-like material from bovine pituitaries. Removal of its O-linked oligosaccharide permits combination with lutropin- $\beta$. J. biol. Chem., 259. 2662-2666.

PIERCE J. G., PARSONS T. F., 1981. Glycoprotein hormones: structure and function. Ann. Rev. Biochem., 50, 465-495.

STARZEC A., 1987. Biosynthèse et maturation des sous-unités $x$ et $\beta$ de la lutropine $(L H)$ chez le rat. Régulation par la gonadolibérine $(G n R H)$. Sc. D. Thesis, Univ. Paris 6. 
STARZEC A., COUNIS R., JUTISZ M., 1986. Gonadotropin-releasing hormone stimulates the synthesis of the polypeptide chains of luteinizing hormone. Endocrinology, 119, 561-565.

TAKATSUKI A., ARIMA K., TAMURA G., 1971. Tunicamycin, a new antibiotic. I. Isolation and characterization of tunicamycin. J. Antibiot., 24, 215-233.

TALMADGE K., BOORSTEIN W. R., FIDDES J. C., 1983. The human genome contains seven genes for the $\beta$-subunit of chorionic gonadotropin but only one gene for the $\beta$-subunit of luteinizing hormone. DNA, 2, $281-289$.

TEPPER M. A., ROBERTS J. L., 1984. Evidence for only one $\beta$-luteinizing hormone and no $\beta$-chorionic gonadotropin gene in the rat. Endocrinology, 115, 385-391.

THOMAS P. S., 1980. Hybridization of denatured RNA and small DNA fragments transferred to nitrocellulose. Proc. nat. Acad. Sci. USA, 77, 5201-5205.

TKACZ J. S., LAMPEN J. O., 1975. Tunicamycin inhibition of polyisoprenyl $\mathrm{N}$-acetylglucosaminyl pyrophosphate formation in calf-liver microsomes. Biochem. Biophys. Res. Commun., 65, 248-257.

TRINH K. Y., WANG N. C., HEW C. L., CRIM L. W., 1986. Molecular cloning and sequencing of salmon gonadotropin $\beta$ subunit. Eur. J. Biochem., 159, 619-624.

VOGEL D. L., MAGNER J. A., SHERINS R. J., WEINTRAUB B. D., 1986. Biosynthesis, glycosylation, and secretion of rat luteinizing hormone $\alpha$ - and $\beta$-subunits : Differential effect of orchiectomy and gonadotropin-releasing hormone. Endocrinology, 119, 202-213.

Le Directeur de la publication: G. DUBOIS

Jouve, 18, rue Saint-Denis, 75001 Paris

Dépôt légal: Octobre 1988. No d'impression : 50494

CCPAP $n^{\circ} 1147$ ADEP 